\title{
CURRENT SITUATION IN TEACHING PHYSICAL EDUCATION AT UNIVERSITIES IN THE SLOVAK REPUBLIC
}

\author{
Alena Buková ${ }^{1}$, Klaudia Zuskova ${ }^{1}$, Agata Horbacz $^{1}$, Erika Chovanová $^{2}$, Natalia Bielikova ${ }^{3}$, \\ Svitlana Indyka ${ }^{3}$ \\ ${ }^{1}$ Institute of Physical Education and Sport, Pavol Jozef Šafárik University in Košice, Slovak Republic, \\ alena.bukova@upjs.sk \\ ${ }^{2}$ Faculty of Sports, Prešov University in Prešov, Slovak Republic \\ ${ }^{3}$ Lesya Ukrainka Eastern European National University, Lutsk, Ukraine \\ https://doi.org/10.29038/2220-7481-2020-02-38-43
}

\begin{abstract}
s
The aim of the study was to draw an accurate picture of the current situation in teaching physical education at universities in the Slovak Republic. The authors seek further ways of sustaining and developing it as a prerequisite for a healthy lifestyle of the university population. The analysis confirmed that technical universities in Slovakia show a substantially more positive approach towards physical education in their curriculum than social and natural sciences universities. Of the 105 monitored faculties of public universities, physical education is listed as a compulsory subject at 13 out of 27 faculties of technical universities and only at 9 out of 78 faculties with a humanities focus. Physical education is present at every faculty of technical universities in our research; the situation is much less favorable at all other universities, where as many as 45 faculties do not offer physical education in their curriculum. Among them are faculties that educate future primary and secondary school teachers. We further found that directly affiliated university departments of Physical Education have a better chance of maintaining sport and physical activity at university, whether as compulsory part of the higher education curricula or as extracurricular optional sporting activities.
\end{abstract}

Key words: Physical education, curricula, university students, physical activity, universities, departments of physical education.

Алена Букова, Клаудія Зускова, Агата Горбач, Еріка Чованова, Наталія Бєлікова, Світлана Індика. Сучасна ситуація викладання фізичного виховання в університетах Словаччини. Мета дослідження скласти точну картину сучасної ситуації з викладання фізичного виховання в університетах Словаччини. Важливо знайти подальші шляхи його підтримання та розвитку як необхідну умову здорового способу життя в університетах. Аналізом підтверджено, що технічні університети Словаччини демонструють значно більш позитивний підхід до фізичного виховання у своїй навчальній програмі, ніж університети соціальних і природничих наук. Зі 105 факультетів державних університетів, що відстежуються, фізичне виховання занесено до обов'язкового предмету в 13 з 27 факультетів технічних університетів і лише на 9 із 78 факультетів, що мають гуманітарну спрямованість. Фізичне виховання присутнє на кожному факультеті технічних університетів у нашому дослідженні; ситуація значно менш сприятлива у всіх інших університетах, де аж 45 факультетів не пропонують фізичну культуру у своїй навчальній програмі. Серед них - факультети, які виховують майбутніх учителів початкових і середніх шкіл. Крім того, з'ясувано, що безпосередньо пов'язані з університетом відділи фізичного виховання мають більше шансів на підтримку спорту та фізичної активності в університеті, як обов'язкові в навчальних програмах вищої освіти, так і як позашкільні факультативні заняття спортом.

Ключові слова: фізичне виховання, навчальні програми, студенти, фізичні навантаження, університети, кафедри фізичного виховання.

Алена Букова, Клаудия Зускова, Агата Горбач, Эрика Чованова, Наталья Беликова, Светлана Индыка. Современная ситуация преподавания физического воспитания в университетах Словакии. Цель исследования - составить точную картину современной ситуации по преподаванию физического воспитания в университетах Словакии. Нужно найти дальнейшие пути его поддержания и развития как необходимое условие здорового образа жизни в университетах. Анализом подтверждается, что технические университеты Словакии демонстрируют значительно более позитивный подход к физическому воспитанию в своей учебной программе, чем университеты социальных и естественных наук. Из 105 факультетов государственных университетов, которые участвовали в исследовании, физическое воспитание относится к обязательному предмету в 13 из 27 факультетов технических университетов и только на 9 из 78 факультетов, имеющих гуманитарную направленность. Физическое воспитание присутствует на каждом факультете технических университетов в нашем исследовании; ситуация гораздо менее благоприятна во всех других университетах, где 45 факультетов не предоставляют физическую культуру в своей программе. Среди них - факультеты, которые готовят будущих учителей начальных и средних школ. Кроме того, мы выяснили, что непосредственно связанные с университетом отделы физического воспитания имеют больше шансов на поддержку спорта и физической активности 
в университете, как обязательные в учебных программах высшего образования, так и как внешкольные факультативные занятия спортом.

Ключевые слова: физическое воспитание, учебные программы, студенты, физические нагрузки, университеты, кафедры физического воспитания.

Introduction. The transition from high school to university is an important milestone in the lifestyle of adolescents. According to several authors $[5 ; 8 ; 19]$, it is a process characterized by change, ambiguity and adjustment in a number of the most important areas of life. In this respect, it is unique to each individual.

Many experts report that a radical decline in interest in regular physical education (PE) and sports activities is obvious as early as at transition from secondary school $[5 ; 9 ; 17 ; 20]$. Most of us recognize the importance of physical activity for maintaining healthy mental and physical development. After completion of compulsory schooling, with participation in exercise in PE classes, there is a substantial loss of interest in regular PE and sports activities $[11 ; 14]$.

Lack of interest in physical activity (PA) during higher education (university) is built upon previously declining engagement in secondary school-based PA. Healthy lifestyle behaviours involving PA are commencing and further developing prior to entering university. Thus, students' indifference at university can be rooted in often negative experience from PE classes at secondary school. It may prevent them from getting acquainted with the opportunities the university offers them in the form of various sports activities.

Considering the amount of time adolescents spend at school, it is a key setting for providing comprehensive support for a healthy lifestyle, including PA and nutrition education. The level of psychological stress that students are exposed to during demanding university studies must be consciously compensated for by systematic, most appropriately daily PA. However, psychotropic substances are frequently taken to cope with stress instead, which, according to Chebeň [13], has become a trendy dangerous substitute. University environment should support students' participation in PA by their easy access, affordability, infrastructure improvements, convenient location of recreational facilities, and the aesthetic design of existing campuses [18].

Nobody doubts the importance of PE and physical and sports activities at universities. University is an important institution supporting health policy [15]. PE is considered an important means of maintaining and developing the physical fitness of students. It compensates for a sedentary lifestyle, relaxation a form of relaxation [10]. However, as the author claims, its importance in developing behaviours and principles of a healthy lifestyle, for students to bring into practical life after graduation, is not sufficiently emphasized. The behaviour in relation to PA that students develop at university has a long-term character and further influence on their PA habits in adulthood. As a result, such patterns are likely to last longer [22]. Conversely, a decrease in PA during the first months of university attendance may lead to a pattern of inactivity that persists throughout the study period, or even after graduation [5]. According to standards developed by the World Health Organization for everyday PA, university students can be classified as a group of inactive people with a strong tendency to a sedentary lifestyle (WHO, 2010). On the other hand, the university can play an important role in forming one's opinions on PA and sport $[5 ; 6 ; 7 ; 12]$ and has the potential to involve a large number of students in behaviour change interventions $[1 ; 16]$.

The aim of study was to map the current situation in providing curricular PE at universities in the Slovak Republic. A further intention was to draw the way forward to its development as a prerequisite for a healthy lifestyle of the university population.

Methods. The data obtained are the result of analysis of teaching PE and sports within the curricula of 20 public universities, of which 4 were technical and 16 natural and social sciences universities. The study did not include state universities (e.g. the Academy of the Police Force), private and foreign universities operating in Slovakia. The data collected were organized in tables and interpreted using logical methods of analysis (factual analysis).

\section{Current State of Teaching PE at Universities}

The presence of PE at universities is still unclear and inconsistent [2]. After year 1989, as a result of overall social changes, there were fundamental changes in higher education. With the introduction of the study credit system and the reduction of hours of direct contact, PE was excluded from the basic study program [14]. Such trend has long existed in a majority of schools in the rest of Central and Western Europe, with a substantial difference though that the students of these schools are raised from an early age to awareness of the importance of a healthy lifestyle. In addition, the implementation of PA at universities there is much better supported with PE equipment and facilities. 
Gradually, at all universities and colleges, the inclusion of PE in the study programs of faculties became dependent on the will of the management of universities and faculties and their academic senates. An important role here is played by people who have a positive attitude towards PE and thus can influence the decision-making boards by showing such interest. In most cases, however, the financial condition of the faculty plays a role as well; the pressure on introducing austerity measures resulted in many universities in the restriction or even elimination of PE. At the same time, few people realize that PE and sports activities at universities are often the only compensation for the hypokinetic lifestyle of a student whose daily routine is dominated by being seated in classes, continuing with sedentary after-school study and predominantly spending a further passive freetime, e.g. going out with friends, classmates.

University students form a significant group of the young adult population. We currently have 35 universities in Slovakia (20 universities and public colleges, 3 state-owned and 12 private). Compared to year 1989 (13 universities/colleges), this is a substantially higher number. However, this only represents $20 \%$ of the total number of young adults (aged 20-29), a fact that has also been confirmed by data from Eurostat (2020) showing the number of population with completed tertiary education. As many as 23 percent of Slovakia's population has a tertiary education, while the EU average is comparably higher (29,5\%). In terms of higher education, Romania is ranking the worst (16\%), while Luxembourg is top of the rank (41\%).

Currently, there are universities in Slovakia where PE is still listed as a compulsory subject in the first or even higher years of study. In most cases, these are technical universities. As presented in Table 1, at these universities PE is provided either as a compulsory $(48,1 \%)$ or as an optional course $(51,9 \%)$. PE is present at all of these faculties one way or another. Perhaps the most encouraging situation is at the Technical University in Košice (TU Košice), where all faculties have PE included in their study programs as a compulsory subject.

Table 1

Inclusion of PE at Technical Universities

\begin{tabular}{|l|l|l|l|l|l|l|}
\hline University & \multicolumn{2}{|c|}{$\begin{array}{l}\text { No. of Faculties/ } \\
\text { Undergraduates }\end{array}$} & $\begin{array}{c}\text { No. of PE } \\
\text { Dept. }\end{array}$ & $\begin{array}{c}\text { PE } \\
\text { Compul- } \\
\text { sory }\end{array}$ & $\begin{array}{c}\text { Elective } \\
\text { and } \\
\text { Optional }\end{array}$ & $\begin{array}{l}\text { No } \\
\text { PE }\end{array}$ \\
\hline $\begin{array}{l}\text { Slovak U. of Technology in } \\
\text { Bratislava }\end{array}$ & 7 & 10,884 & 5 & 4 & 3 & $\mathbf{0}$ \\
\hline The Technical U. of Košice & 9 & 8,053 & $1 \mathrm{sh}^{*}$ & 8 & 0 & $\mathbf{0}$ \\
\hline The U. of Žilina & 7 & 7,723 & $1 \mathrm{sh}^{*}$ & 0 & 7 & $\mathbf{0}$ \\
\hline Technical U. in Zvolen & 4 & 2,496 & $1 \mathrm{sh}^{*}$ & 1 & 4 & $\mathbf{0}$ \\
\hline Total: 4 universities & $\mathbf{2 7}$ & $\mathbf{2 9 , 1 5 6}$ & $\mathbf{5 + 3 s h ^ { * } / \mathbf { 2 0 }}$ & $\mathbf{1 3}$ & $\mathbf{1 4}$ & $\mathbf{0}$ \\
\hline
\end{tabular}

$1 s h^{*}$ - one shared PE department at the university.

The situation is completely different at social sciences and natural science universities (table 2). Only 9 faculties out of $78(11,5 \%)$ offer students compulsory PE at least in the first year, many more faculties provide PE only as an optional course $(30,8 \%)$. Yet, at most faculties PE is completely absent. It makes up almost $60 \%$ of faculties $(57,7 \%)$. Among them are also faculties that educate future teachers at primary and secondary schools.

Table 2

Inclusion of PE at Social and Natural Sciences Universities

\begin{tabular}{|c|c|c|c|c|c|c|}
\hline University & $\begin{array}{l}\text { No. o } \\
\text { Unde }\end{array}$ & $\begin{array}{l}\text { culties/ } \\
\text { duates }\end{array}$ & $\begin{array}{c}\text { No. of PE } \\
\text { Depts./Insti- } \\
\text { tues }\end{array}$ & $\begin{array}{c}\text { PE } \\
\text { Compul- } \\
\text { sory }\end{array}$ & $\begin{array}{c}\text { Elective } \\
\text { and } \\
\text { Optional }\end{array}$ & $\begin{array}{l}\text { No } \\
\text { PE }\end{array}$ \\
\hline 1 & 2 & 3 & 4 & 5 & 6 & 7 \\
\hline Comenius U. in Bratislava & $13^{* *}$ & 22,245 & 9 & 5 & 3 & 4 \\
\hline U.of Prešov in Prešov & $8 * *$ & 8,055 & 1 & 0 & 1 & 6 \\
\hline $\begin{array}{l}\text { Constantine the Philosopher U. in } \\
\text { Nitra }\end{array}$ & 5 & 7,414 & $1+\mathrm{PED}^{*}$ & 0 & 1 & 4 \\
\hline U.of Economics in Bratislava & 7 & 7,227 & $1 \mathrm{sh}^{*}$ & 1 & 5 & 1 \\
\hline Pavol Jozef Šafárik U. in Košice & $5+1$ & 7,096 & $1 \mathrm{sh}^{*}$ & 1 & 4 & $\mathbf{0}$ \\
\hline
\end{tabular}


End of the Table 2

\begin{tabular}{|l|c|c|c|c|c|c|}
\hline \multicolumn{1}{|c|}{$\mathbf{1}$} & $\mathbf{2}$ & $\mathbf{3}$ & $\mathbf{4}$ & $\mathbf{5}$ & $\mathbf{6}$ & $\mathbf{7}$ \\
\hline Matej Bel U.in B.Bystrica & 6 & 6,448 & $1+\mathrm{PED}^{*}$ & 0 & 1 & $\mathbf{5}$ \\
\hline Slovak U.of Agriculture in Nitra & 6 & 6,250 & $1 \mathrm{~s}^{*}$ & 0 & 6 & $\mathbf{0}$ \\
\hline $\begin{array}{l}\text { U.of SS. Cyril and Methodius in } \\
\text { Trnava }\end{array}$ & $4+1$ & 5,459 & 0 & 0 & 1 & $\mathbf{4}$ \\
\hline Trnava U.in Trnava & 5 & 4,284 & 0 & 0 & 0 & $\mathbf{5}$ \\
\hline Catholic U. in Ruzomberok & 4 & 3,454 & 1 & 1 & 0 & $\mathbf{3}$ \\
\hline Alexander Dubček U. of Trenč́n & 4 & 1,993 & 1 & 1 & 0 & $\mathbf{3}$ \\
\hline $\begin{array}{l}\text { The U. of Veterinary Medic. and } \\
\text { Pharmacy in Košice }\end{array}$ & 1 & 1,869 & 1 & 0 & 1 & $\mathbf{0}$ \\
\hline J. Selye University & 3 & 1,658 & 1 & 0 & 1 & $\mathbf{2}$ \\
\hline $\begin{array}{l}\text { Academy of Performing Arts in } \\
\text { Bratislava }\end{array}$ & 3 & 982 & 0 & 0 & 0 & $\mathbf{3}$ \\
\hline $\begin{array}{l}\text { Academy of Fine Arts and Design } \\
\text { in Bratislava }\end{array}$ & 1 & 644 & 0 & 0 & 0 & $\mathbf{1}$ \\
\hline Academy of Arts in B.Bystrica & 3 & 556 & 0 & 0 & 0 & $\mathbf{3}$ \\
\hline Total: 16 univesities & $\mathbf{7 8}$ & $\mathbf{8 5 , 6 3 4}$ & $\mathbf{1 6 + 3 s h / 1 7}$ & $\mathbf{9}$ & $\mathbf{2 4}$ & $\mathbf{4 5}$ \\
\hline
\end{tabular}

$1 s h^{*}$ - one shared PE department at the university.

** No. of faculties, including the Faculty of Sports.

*PED-Department at one of the faculties where they educate PE teachers and coaches.

There are many universities in Slovakia, where PE is provided by one shared university department of PE. These were integrated in 1981 by merging the faculty departments of PE, which until that time were present at each faculty [3]. At technical universities, there are 3 joint PE departments providing classes for 20 faculties. There are another 3 joint PE departments at other universities, which provide PE for a further 17 faculties. It follows that, despite the fact that there are only 6 shared PE departments in Slovakia, they provide PE for 37 faculties. As Bobrík [4] claims, in terms of pedagogical and organizational connection to the faculties, the idea of shared PE departments was a step backwards, althought at the same time he claims that certain positives apsects are also manifested here. The departments gained a relatively broad autonomy in the new organizational form and were able to directly decide on their existential and professional issues, they further increased activity in the field of scientific research and qualification growth, which had a great impact on the social and economic status of PE department teachers. In our opinion, shared PE departments have another great advantage - they can offer students a wider range of sports activities. Of course, this fact is also influenced by the availability of equipment and facilities at the particular universities, as well as its size. Central PE departments are suitable for smaller universities (up to 10,000 students). Sush is the case with universities in Slovakia, with the exception of two universities (both are in Bratislava, the capital of the Slovak Republic) which have a higher number of students. And both universities in the capital have PE departments directly in their faculties. However, the shared PE departments at smaller universities are also justified in the case of a suitable disposition of individual faculties in relation to the sports facilities available. Based on our onw experience, we can confirm that students who have sports facilities within reach of their school, college or youth hostel are more inclined to the PE classes offered by their university.

Conclussion. We agree with the findings of Somorovsky and Kyselovičová [21], who claim that the compulsory PE in the 1st year of study is inevitable as the nature of students' daily routine is formed in a fundamental way in that period. Also, several authors, including us, have found that the amount of PA further decreases during university studies $[15 ; 19 ; 23]$. A considerable finding is that 1 st year university students with compulsory PE classes were more likely to go on doing P Huang A in upper grades. Based on new experiences and gaining interest in PA, which differs significantly from PE in high school, they further participate in PE in higher years of study, either in the form of optional PE or even beyond credit-based PE.

The university should aim to create conditions for meaningful leisure time through a wide range of classic, but also lesser-known or non-traditional sports, which attract different interest-groups of young people. Every university should place particular emphasis on providing them with proper conditions for sports activities, since PE is basically the only compensation for the hypokinetic behavior of a university student. At the same time, it is a form of active compensation for the significant mental burden of studying at 
university. Sports performance and competitiveness do not have to be necesssarily dominant elements of the subject. Health promotion should prevail.

The sports offered by PE departments should be aimed at the interest of students with regard to their individuality and physical and mental health. One of the ways is to offer a variety of sports students can choose from according to interest, skill level and physical condition, taking into account their state of health, ranging from classic sports - collective and individual, to aesthetic and combat sports. In order to make the offer more attractive, we propose to include adrenaline sports, lesser-known and non-traditional sports. One of the possibilities to «revive» the offer of sports is the introduction of so-called «Physical activities to reduce stress». This form of activity would include various breathing exercises, compensatory and balancing exercises, as well as elements from yoga, Pilates and the like. Also, the further the more weight loss activities are needed, where staff would create a program specifically designed for the particular student, including adjusting the diet,and to suit his or her interests and state of health.

Universities are an important environment for leisure activities, as university students spend a great deal of time in this environment. For the above reason, the university, in cooperation with the Ministry of Education, Science, Research and Sports of the Slovak Republic, should improve the physical environment of the university. Emphasis has to be put on the development of infrastructure for active leisure, creating suitable conditions for physical and sports activities and targeted interventions into the movement regime of university students during study. This could also slow down the outflow of students to the west, where students have better conditions not only for study but also for leisure activities.

If young people, including university students, are not to degrade physically, quick and effective solutions are needed.

\section{References}

1. Blahutková, M., Lepková, H. (2017). [Movement as a coping strategy in coping with stress in university students]. University PE and sports, physical activity and a healthy lifestyle - a peer-reviewed collection of scientific works. Košice, 23-27 [in Czech].

2. Bobrík, M. (2016). [The state of physical education and sport at universities in the Slovak Republic in 2010 and 2016]. Physical education \& sport, XXVI, 3, 35-40. ISSN 1335-2245 [In Slovak].

3. Bobrík, M. (2011). [Departments of physical education and sports in confrontation with the past and present]. Academic sport. Proceedings of scientific works, 116-129. SAUŠ Bratislava. ISBN: 978-80-552- 0696-7 [In Slovak].

4. Bobrík, M. (1997) [As well as at the departments of physical education of universities in Slovakia]. Physical education \& sports, 7/2, 10-12 [In Slovak].

5. Bray, SR. A Born, HA. (2014). Transition to university and vigorous physical activity: Implications for health and psychological well-being. J. Am.College Health, 52/4, 181-8.

6. Buková, A. (2002). [Physical activity in the way of life of a university student]. Half a century of physical education at universities scientific conference. Praha, 162-67 [In Slovak].

7. Buková, A. (2009). [Lifestyle analysis of UPJŠ students]. Proceedings of abstracts and papers of the international conference, Brno: 23-30 [In Slovak].

8. Deforche, B., Van Dyck, D., Deliens, T. et al. (2015). Changes in weight, physical activity, sedentary behaviour and dietary intake during the transition to higher education: a prospective study. Int $\mathrm{J}$ Behav Nutr Phys Act 12/16 https://doi.org/10.1186/s12966-015-0173-9

9. Douglas, K. A., Collins, J. L., Warren, C. et al. (1997) Results from the 1995 National College Health Risk Behavior Survey. Journal of American College Health, 46, 55-66.

10. Drnek, J. (2013). [Teaching physical education at universities in the Czech Republic]. Musculoskeletal and health, p. 119-125. Brno, Paido [in Czech].

11. Eurostat, (2020). http://appsso.eurostat.ec.europa.eu/nui/submitViewTableAction.do taken on 2020/06/02

12. Gajdošík, J., Balášs, J. (2012). [Interest in physical activities among medical students at Charles University]. Sportiva Studio, 6/2, 62-9 [in Czech].

13. Chebeň, D. (2012). [Physical activities and their impact on the health of university students]. Proceedings Sports and recreation. UKF PF KTVŠ Nitra, 46-48 [In Slovak].

14. Junger, J. (2009). [Physical activity of university students as a necessary need for their development and compensation of study load]. Slovak school sport: conditions-forecasts-development. National conference on school sports Štrbské Pleso. SAUŠ: 176-84 [In Slovak].

15. Korn, L, Gonen, E, Shaked, Y, Golan, M. (2013). Health perception, self and body image, physical activity and nutrition among undergraduate students in Israel. PLOS one, 8/3.

16. Plotnikoff, R. C, Costigan, S. A, Williams, R. L. et. al. (2015). Effectiveness of interventions targeting physical activity, nutrition and healthy weight for university and college students a systematic review and metaanalysis. Int. J. of Behavioral Nutrit. and Physical Activity, 12: 45. 
17. Racette, S. B., Deusinger, S., Strube, M. J. et al. (2008). Changes in weight and health behaviors from freshman through senior year of college. J. Nutr. Educ. Behav., 40, 39-42.

18. Reed, J. (2007). Perception of the availability of recreational physical activity facilities on a university campus. J. Am. College of Health, 55, 189-94.

19. Small, M., Bailey-Davis, L., Morgan, N. et al. (2013a). Changes in Eating and Physical Activity Behaviors Across Seven Semesters of College: Living On or Off Campus Matters. Health Education \& Behavior, 40/3. https://doi.org/10.1177/1090198112467801

20. Small, M. L, Morgan, N, Bailey-Davis, L. A Maggs, J. L. (2013b). The protective effects of parent-college student communication on dietary and physical activity behaviors. J. of Adolescent Health, 53, 300-02.

21. Somorovský, I., Kyselovičová, O. (2017). [Differentiated movement programs: Effectiveness on selected somatic, functional and biochemical characteristics of female students]. 112 p. ISBN 978-80-89075-59-1 [In Slovak].

22. Sparling, P. B. A Snow, T. K. (2002). Physical activity paterns in recent college alumni. Res. Quart. for Exercise and Sport, 73, 200-05.

23. Zusková, K, Buková, A. et. al. (2015). [Overweight and obesity in university students - selected aspects of lifestyle and psyche]. Košice, 170 p. [In Slovak].

Стаття надійшла до редакції 22.05.2020 p. 